\title{
Comparative Performance Evaluation of Pelton Wheel and Cross Flow Turbines for Power Generation
}

\author{
Oyebode $0 . .^{1 *}$ and Olaoye J. $0 .{ }^{2}$ \\ 'Department of Food, Agricultural and Biological Engineering, Kwara State University, Malete, Kwara State, Nigeria. \\ 2Department of Agricultural and Biosystems Engineering, University of Ilorin, Ilorin, Kwara State, Nigeria. \\ ORCID: Oyebode (0000-0003-1094-1149)
}

\begin{abstract}
The performance of two micro hydro power turbines (Pelton Wheel and Cross Flow Turbines) were evaluated at the University of Ilorin (UNILORIN) dam. The Dam has a net head of $4 \mathrm{~m}$, flow rate of $0.017 \mathrm{~m}^{3}$ and theoretical hydropower energy of $668 \mathrm{~W}$. The two turbines were tested and the optimized value of operating conditions namely; angle of inclination ( $15^{\circ}$ above tangent, tangential and $15^{\circ}$ below tangent), height to impact point $(200 \mathrm{~mm}, 250 \mathrm{~mm}$ and $300 \mathrm{~mm})$ and length to impact point $(50 \mathrm{~mm}, 100 \mathrm{~mm}$ and $150 \mathrm{~mm}$ ) were pre-set at their various levels for both Turbines. The optimum values of the process output or measured parameters were determined statistically using a $3^{3} \mathrm{X} 2$ factorial experiment in three replicates. An optimum Turbine speed (538.38rpm) in off load condition was achieved at $250 \mathrm{~mm}$ height to impact point, $150 \mathrm{~mm}$ length to impact point and angle at tangential inclination. Similar combination also yielded an optimum turbine torque of $46.16 \mathrm{kNm}$ for Pelton Wheel Turbine. For the Crossflow Turbine, an optimum turbine speed of 330.09rpm was achieved by pre-setting $250 \mathrm{~mm}$ height to impact point, $100 \mathrm{~mm}$ length to impact point and $15^{\circ}$ below tangent. Same combination also yielded an optimum turbine torque of $39.07 \mathrm{kNm}$. The optimum Turbine speed $(392.02 \mathrm{rpm})$ in on-load condition was achieved at $250 \mathrm{~mm}$ height to impact point, $150 \mathrm{~mm}$ length to impact point and angle at tangential inclination. Similar combination also yielded an optimum Turbine Torque of $36.46 \mathrm{kNm}$, optimum Alternator speed of $1768.56 \mathrm{rpm}$ and an optimum output voltage of $7.87 \mathrm{~V}$ for Pelton Wheel Turbine while for Cross Flow Turbine, an optimum Turbine Speed of $197.66 \mathrm{rpm}$ was achieved by pre-setting $250 \mathrm{~mm}$ height to impact point, $100 \mathrm{~mm}$ length to impact point and $15^{\circ}$ below tangent. Same combination also yielded an optimum Turbine Torque of $25.02 \mathrm{kNm}$, optimum Alternator speed of $879.24 \mathrm{rpm}$ and an optimum output voltage of $4.05 \mathrm{~V}$. Hence, from the results obtained, it was observed that the most efficient turbine at these preset conditions was the Pelton Wheel Turbine. This shows that if adequately optimized, the Pelton wheel can perform effectively at low heads.
\end{abstract}

Key words: Small hydropower, Pelton wheel turbine, Cross flow turbine, power generation, Dams

\section{INTRODUCTION}

Hydropower plants use the motion of water from sources such as the ocean, rivers and waterfalls to move vane-like blades in a turbine which turns a shaft connected to a generator. The generator has a powerful electromagnet (a rotor) which is turned inside a coil of copper bars (a starter). This produces an electromotive force or the process of exciting electrons to jump from atom to atom. When electrons flow along a wire or other conductor, jumping from atom to atom, they create an electric current or a flow of electricity. The first hydropower supply station in Nigeria is at Kainji on the river Niger where the installed capacity is $836 \mathrm{MW}$ with provisions for expansion to $1156 \mathrm{MW}$. A second hyd- ropower station on the Niger is at Jebba with an installed capacity of $540 \mathrm{MW}$. An estimate by Aliyu and Elegba [2] for rivers Kaduna, Benue and Cross River (at Shiroro, Makurdi and Ikom, respectively) put their total capacity at about 4,650MW. Estimates for the rivers on the Mambila Plateau are put at 2,330MW. The foregoing assessment is for large hydro schemes which have predominantly been the class of schemes in use prior to the oil crisis of 1973. Since that time, however, many developed and developing countries have opted for small scale hydropower with appreciable savings made over the otherwise alternative to crude oil. It should be noted that hydropower plants that supply electrical energy between the range of $15 \mathrm{~kW}$ to $15 \mathrm{MW}$ are mini-hydro while those supplying below $15 \mathrm{~kW}$ are normally referred to
*Corresponding authour

Email: oyebodeoyetayo@yahoo.com
European Mechanical Science, March 2019; 3(1): 6-12 doi: https://doi.org/10.26701/ems.449884

Received: August 1, 2018

Accepted: November 14, 2018 
as micro-hydro plants [10]. Indeed, small scale (both micro and mini) hydropower systems possess so many advantages over large hydro systems, which includes ease of setting up, low maintenance requirement, less skilled operators required and the problems of topography is minimal. In effect, small hydropower systems can be set up in all parts of the country so that the potential energy in the large network of rivers can be tapped and converted to electrical energy. In this way the nation's rural electrification projects can be greatly enhanced. Hydropower has been regarded as the ideal fuel for electricity generation because, unlike the non-renewable fuels used to generate electricity, it is almost free, there are no waste products, and hydropower does not pollute the water or the air. However, it is criticized because it does change the environment by affecting natural habitats and large hydropower schemes have been considered a weapon of mass destruction in case of failure or attack during war [4].

Furthermore, the estimated long-term power demand of Nigeria was 25GW for the year 2010 to sustain industrial growth [6]. The Power Holding Company of Nigeria (PHCN, as it was then called) has an installed capacity of only $6 \mathrm{GW}$, out of which less than $2.5 \mathrm{GW}$ is the actual available output. Of this, thermal plants provide $61 \%$, while hydropower generation is about $31 \%$ [7]. This shows a gross underdevelopment of the hydropower potentials of Nigeria. Developing micro hydropower could therefore be a solution to the inadequate power supply from the national grid especially to rural areas. It can as well be a key driver in rural development programs.

The cross-flow turbine has a drum-shaped runner consisting of two parallel discs connected near their rims by a series of curved blades [5]. A Cross flow turbine always has its runner shaft horizontal (unlike turbine which can have either horizontal or vertical shaft orientation). They will work on net heads from just $1.75 \mathrm{~m}$ all the way to $200 \mathrm{~m}$, though there are more appropriate turbine choices for sites with heads above $40 \mathrm{~m}$. They will work on average annual flows as low as $401 / \mathrm{s}$ up to $5 \mathrm{~m}^{3} / \mathrm{s}$, though on the higher flow rates there may be other better turbine types to consider.

The peak efficiency of a cross-flow turbine is somewhat less than a Kaplan, Francis or Pelton turbine. However, the crossflow turbine has a flat efficiency curve under varying load. With a split runner and turbine chamber, the turbine maintains its efficiency while the flow and load vary from $1 / 6$ to the maximum [3]. Since it has a low price, and good regulation, cross-flow turbines are mostly used in mini and micro hydropower units of less than two thousand $\mathrm{kW}$ and with heads less than 200m [9].

Pelton wheel on the other hand, is a water impulse turbine. It was invented by Lester Allan Pelton in the 1870s [13]. The Pelton wheel extracts energy from the impulse of moving water, as opposed to its weight like traditional overshot water wheel. Although many variations of impulse turbines existed prior to Pelton's design, they were less efficient than Pelton's design; the water leaving these wheels typically still had high speed and carried away much of the energy [4]. For maximum power and efficiency, the turbine system is designed such that the water-jet velocity is twice the velocity of the bucket. A very small percentage of the water's original kinetic energy will remain in the water; however, this allows the bucket to be emptied at the same rate it is filled, thus allowing the water flow to continue uninterrupted [7]. Often two buckets are mounted side-by-side, thus splitting the water jet in half. This balances the side-load forces on the wheel, and helps to ensure smooth, efficient momentum transfer of the fluid jet to the turbine wheel [5]. Because water and most liquids are nearly incompressible, almost all the available energy is extracted in the first stage of the hydraulic turbine. Therefore, Pelton wheels have only one turbine stage, unlike gas turbines that operate with compressible fluid [3]. Pelton wheels are the preferred turbine for hydro-power, when the available water source has relatively high hydraulic head at low flow rates, where the Pelton wheel is most efficient. Thus, more power can be extracted from a water source with high-pressure and low-flow than from a source with low-pressure and high-flow, even when the two flows theoretically contain the same power [11].

The overall potential of hydropower generation of Nigeria is in excess of $11 \mathrm{GW}$ out of which less than $2 \mathrm{GW}$ has been utilized [14]. This means that less than $20 \%$ of the hydropower potential of the country has been realized. The development of a micro hydropower turbine is therefore desirable. The objectives of this research were to carry out performance evaluation of two existing hydro-electric power turbines, investigate the optimum pre-set conditions and establish the most efficient of the hydropower turbines for the overflow from UNILORIN Dam. This becomes necessary because even though there are so many existing small hydro-power turbines, the pre-set conditions for their optimal performance seem not to be handy. Also, selecting amongst the numerous turbines available may sometimes require the test for compatibility with the particular stream flow.

\section{MATERIALS AND METHODS}

\subsection{Brief Description of the two turbines}

The machine was designed and fabricated by Oyebode [8] and is made up of two Turbines (Cross Flow or Pelton Wheel), Nozzle, Chamber, Alternator, Pulley, Bearing, Shaft, Adjuster, Cover, Frame, etc. Figures 1 and 2 shows the component parts of the Cross Flow and Pelton Wheel Turbines respectively. While Figures 3 and 4 shows the pictorial view of the Pelton Wheel and Crossflow Turbines Respectively. Water moves into the chamber through the nozzle and strikes the turbine. The turbine converts the kinetic energy of the flowing water is into mechanical energy which is in turn converted into electrical energy with the aid of the alternator. 


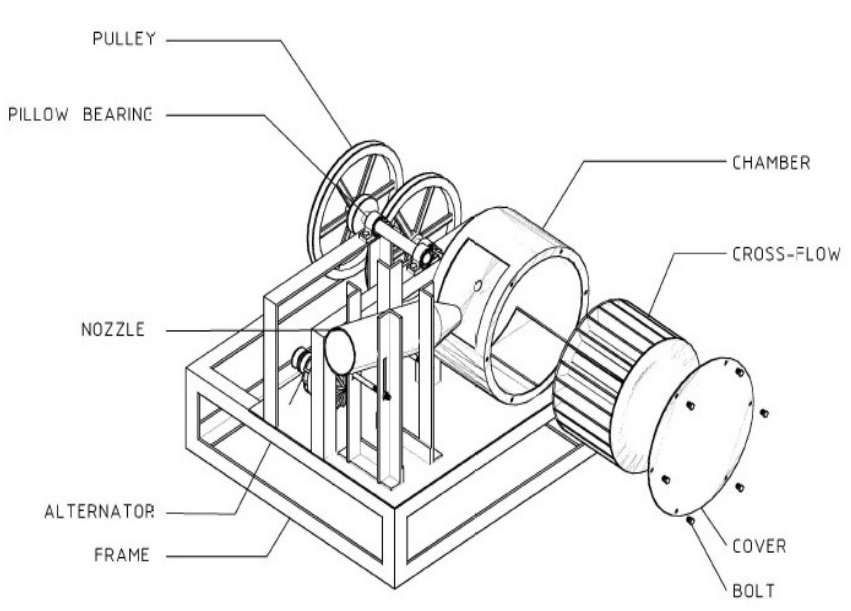

Figure 1:- Description of the Cross Flow Turbine



Figure 2:- Description of the Pelton Wheel Turbine

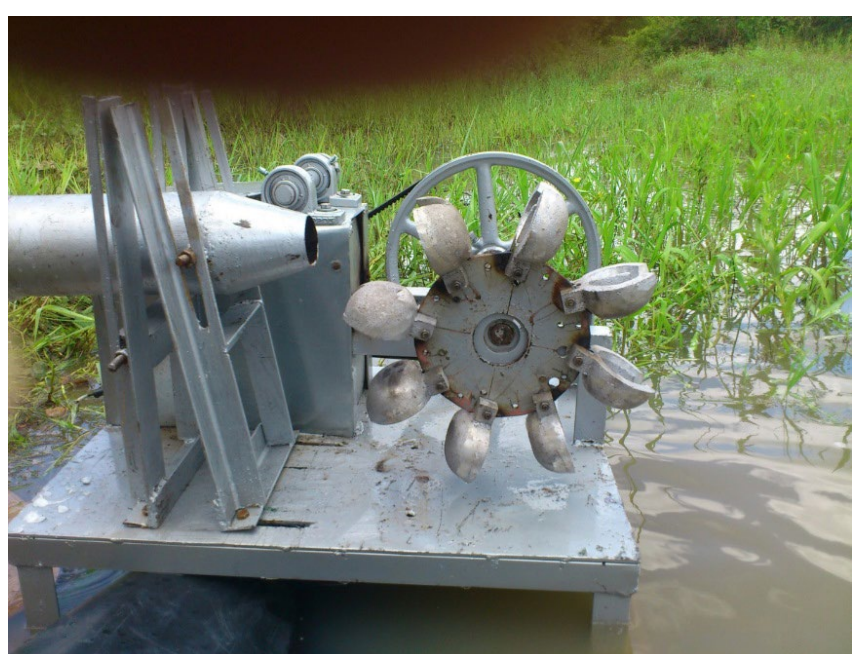

Figure 3:- Pictorial View of the Pelton Wheel Turbine

\subsection{The University of Ilorin (Unilorin) Dam}

Figure 5 shows the pictorial view of the University of Ilorin (UNILORIN) dam. it was commissioned in 2007 primarily for water supply; it is located on the Oyun River. The Dam is a zoned earth fill embankment with an ogee-shaped concrete spillway. The intake for water supply and the low lift pumping station are located on the wing wall.

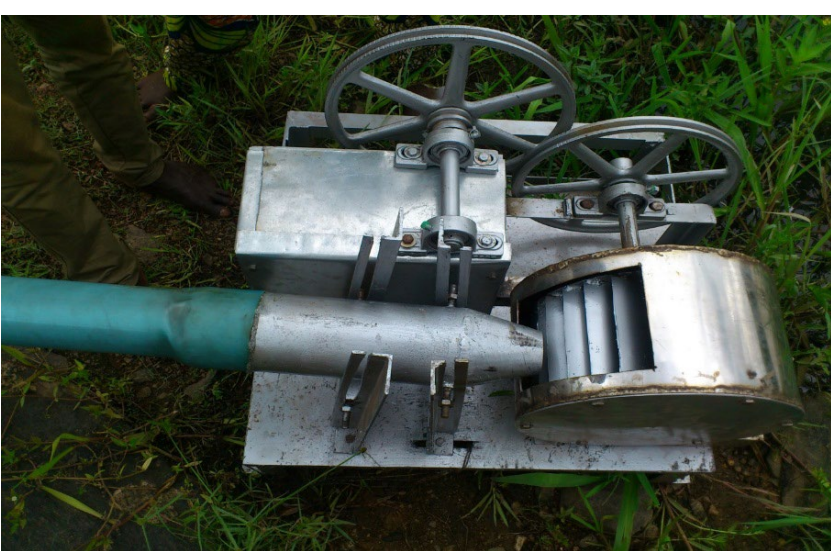

Figure 4:- Pictorial View of the Cross Flow Turbine



Figure 5: Pictorial View of Unilorin Dam Source: Akoshile, and Olaoye [1]

\section{Water Resources of the Dam}

To decide the hydropower potential of any flow, it is important to begin with an evaluation of the available water resource. The energy potential of the scheme is directly proportional to the flow and head. To fairly select the most appropriate hydraulic equipment and estimate the dam's hydropower potential, the water resource analysis took into consideration the water to meet the primary responsibility of the Dam. Considering this, only the water from the spill way was available for use.

\section{Hydraulic Head (h).}

In hydroelectric projects, calculations are based on the available hydraulic head. This is a measurement of the difference in elevation between the water source and the turbine. For this project, the head was measured (using a change in height method) to be $4 \mathrm{~m}$.

\section{Flow Rate (q).}

A portion of the overflow was channelled into a pipe. To measure the amount of water available through the pipe, (known as the flow rate), the water supply was opened, and the amount that flowed out in 10 seconds was collected in a large bucket. Once the experimental time had elapsed, the content of the bucket was measured by pouring it into a measuring cup. The following is a summary of the calculations;

170 litters was collected in 10 seconds 


$$
\begin{gathered}
\text { i.e., } 171 / \mathrm{s} \\
\mathrm{q}=1.7 \times 10^{-2} \mathrm{~m}^{3} \mathrm{~s}^{-1}
\end{gathered}
$$

\section{Available Hydro Power from Unilorin Dam.}

Power $(\mathrm{kW})=$ [Flow Rate] $\mathrm{x}$ [Hydraulic Head] $\mathrm{x}$ [Gravity $\mathrm{x}$ [Density of

Water] x [Efficiency] x [1/1000]

Or

$\mathrm{P}(\mathrm{kW})=\mathrm{q} \times \mathrm{h} \times \mathrm{g} \times \rho \times \eta \times[1 / 1000]$

As this calculation is just designed to give the upper limit, an efficiency of $100 \%$ was assumed.

$\mathrm{P}(\mathrm{kW})=1.7 \times 10^{-2} \times 4 \times 9.81 \times 1000 \times[1 / 1000]=0.66708 \mathrm{~kW}$

Or 667.08Watts

\subsection{Experimental Factors}

The operating conditions manipulated were angle of inclination of the nozzle $\left(15^{\circ}\right.$ above tangent, tangential, and $15^{\circ}$ below tangent; as shown in Figure 6, this is to make the point of impact of the water jet coincide with the Upper part of the cup, the centre of the cup and the lower part of the cup respectively. Height of nozzle to Impact Point $(200 \mathrm{~mm}$, $250 \mathrm{~mm}$ and $300 \mathrm{~mm}$, this is to also make the point of impact of the water jet coincide with the lower part of the cup, the centre of the cup and the upper part of the cup respectively). Length of nozzle to impact point $(50 \mathrm{~mm}, 100 \mathrm{~mm}$ and $150 \mathrm{~mm}$ ). According to Oyebode (2014), the designed valued for the length to impact point was $76 \mathrm{~mm}$. A range above and below this value was thus selected. The effect of these operatingconditions on the various outputs were investigated under two conditions (off-load and on-load) for the two Turbines understudy (Pelton Wheel Turbine and Cross Flow Turbine).The study combines both SPSS 16.0 and Essential Regression computer software. The performance of the turbines was evaluated using a $3^{3} \mathrm{X} 2$ (three factors and three levels under two conditions) factorial experimental design.

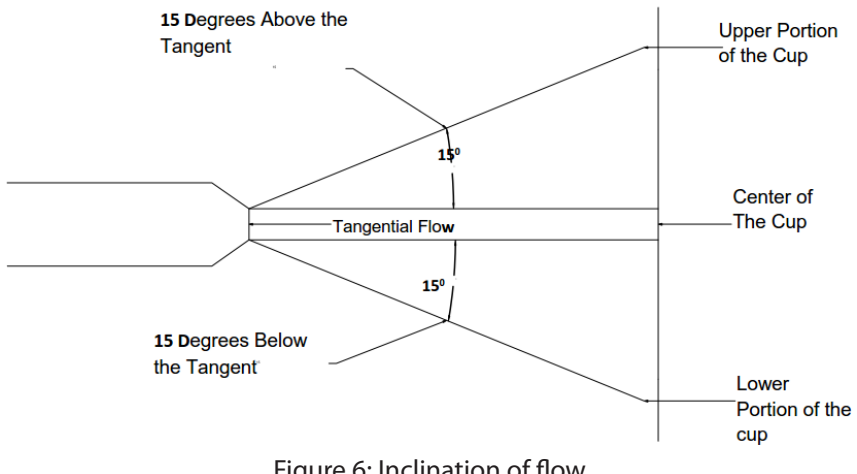

\subsection{Measured Parameters}

i) Speed:-The speed was measured using a tachometer. The nob of the tachometer was placed at the punched center of the shaft and the readings were recorded. The Tachometer used was a contact type and it was manufactured by Fisons.
The model is TAF $-420-\mathrm{K}$ and it has a capacity of 100,000 rpm.

ii) Output Voltage:-The output voltage was measured using a D.C. Multimeter manufactured by Fison. The model is DT9205M and it has a capacity of $1000 \mathrm{~V}$

iii) Torque: - The turbine torque was measured using a hand-held Shimpo FG-7000T-3 Digital Torque Meter

\section{RESULTS AND DISCUSSION}

\subsection{Performance Evaluation}

Descriptive Statistics of Speed of Turbine and Torque using the Various Process Parameter

Table 1 shows the summary statistics of the data collected during the performance evaluation of the two Turbines. It can be inferred from table 4.4 that the mean values of Turbine speed vary depending on the Turbine and the process parameters being employed. Variations in Turbines speed also occurred along the levels of process parameter. Similar pattern was observed for all other output namely; Turbine Torque, Alternator Speed and Output voltage. These may suggest that process parameter manipulated does not have same effect process output/responses.

\subsection{Effect of Load on Turbine Speed and Turbine Torque}

The result of the effect of load on Turbine speed and Turbine Torque is presented on Table 2. It was observed that there was significant shift in mean of both Turbine Speed and Turbine Torque on application of load for both Pelton Wheel Turbine and Cross Flow Turbine at 5\% level of significance. This implies that for both Turbines, there is a loading effect.

It can therefore be concluded that the variation or discrepancies observed in Turbine speed and Turbine Torque was not due to chance occurrence but rather were due to the effect of the load placed on either of the Turbines. This is consistent with the findings of Amiri et.al., [15] that reported the existence of a significant loading effects on the pressure fluctuations exerted on a Kaplan turbine.

Table 3 shows the comparisons between load and off load condition as it affects Turbine speed and Turbine Torque of the two Turbines using the New Duncan Multiple Range Test (DMRT). It was inferred from Table 3 that the mean of Turbine speed was statistically higher in off load condition than in on load condition for both Turbines. Similarly, the mean of Turbine Torque was also significantly higher in off load than in on load condition for both Turbines. 
Table 1: Descriptive Statistics of Speed of Turbine and Torque using the Various Process Parameter

\begin{tabular}{|c|c|c|c|c|c|c|c|c|c|c|}
\hline \multirow{2}{*}{$\begin{array}{c}\text { Process } \\
\text { Parameter }\end{array}$} & \multirow{2}{*}{ Turbine Type } & \multirow{2}{*}{ Level } & \multicolumn{2}{|c|}{ Turbine Speed } & \multicolumn{2}{|c|}{ Turbine Torque } & \multicolumn{2}{|c|}{ Alternator Speed } & \multicolumn{2}{|c|}{ Output Voltage } \\
\hline & & & Mean & Std. Dev. & Mean & Std. Dev. & Mean & Std. Dev. & Mean & Std. Dev \\
\hline \multirow{4}{*}{ Condition } & \multirow{2}{*}{$\begin{array}{l}\text { Pelton Wheel } \\
\text { Turbine }\end{array}$} & Off Load & 428.38 & 55.54 & 36.73 & 4.76 & & & & \\
\hline & & On Load & 301.28 & 38.88 & 28.00 & 3.63 & & & & \\
\hline & \multirow{2}{*}{$\begin{array}{l}\text { Cross Flow } \\
\text { Turbine }\end{array}$} & Off Load & 251.20 & 36.70 & 29.74 & 4.34 & & & & \\
\hline & & On Load & 150.63 & 22.54 & 19.08 & 2.85 & & & & \\
\hline \multirow{6}{*}{$\begin{array}{c}\text { Inclination } \\
\text { (I) }\end{array}$} & \multirow{3}{*}{$\begin{array}{c}\text { Pelton Wheel } \\
\text { Turbine }\end{array}$} & $15^{\circ}$ above & 350.31 & 77.65 & 31.08 & 5.94 & 1304.07 & 173.73 & 6.02 & 0.80 \\
\hline & & Tangential & 400.57 & 76.36 & 35.54 & 5.49 & 1490.44 & 108.63 & 6.88 & 0.50 \\
\hline & & $15^{\circ}$ below & 343.61 & 73.80 & 30.48 & 5.59 & 1283.19 & 154.74 & 5.92 & 0.72 \\
\hline & \multirow{3}{*}{$\begin{array}{l}\text { Cross Flow } \\
\text { Turbine }\end{array}$} & $15^{\circ}$ above & 188.30 & 55.34 & 22.88 & 6.08 & 632.00 & 93.82 & 2.92 & 0.43 \\
\hline & & Tangential & 198.43 & 56.58 & 24.11 & 6.19 & 671.70 & 83.79 & 3.10 & 0.39 \\
\hline & & $15^{\circ}$ below & 216.02 & 62.15 & 26.24 & 6.81 & 724.19 & 101.73 & 3.34 & 0.47 \\
\hline \multirow{6}{*}{$\begin{array}{l}\text { Height to } \\
\text { Impact } \\
\text { Point } \\
\text { (V) }\end{array}$} & \multirow{3}{*}{$\begin{array}{c}\text { Pelton Wheel } \\
\text { Turbine }\end{array}$} & $200 \mathrm{~mm}$ & 345.89 & 72.81 & 30.69 & 5.50 & 1292.74 & 151.44 & 5.97 & 0.70 \\
\hline & & $250 \mathrm{~mm}$ & 342.20 & 73.91 & 30.36 & 5.60 & 1275.26 & 156.81 & 5.89 & 0.72 \\
\hline & & $300 \mathrm{~mm}$ & 406.41 & 76.62 & 36.05 & 5.47 & 1509.70 & 100.11 & 6.97 & 0.46 \\
\hline & \multirow{3}{*}{$\begin{array}{l}\text { Cross Flow } \\
\text { Turbine }\end{array}$} & $200 \mathrm{~mm}$ & 190.81 & 54.39 & 23.18 & 5.94 & 642.63 & 81.32 & 2.97 & 0.37 \\
\hline & & $250 \mathrm{~mm}$ & 222.67 & 61.92 & 27.05 & 6.74 & 746.44 & 97.16 & 3.44 & 0.45 \\
\hline & & $300 \mathrm{~mm}$ & 189.26 & 54.88 & 22.99 & 6.01 & 638.81 & 82.55 & 2.95 & 0.38 \\
\hline \multirow{6}{*}{$\begin{array}{l}\text { Length to } \\
\text { Impact } \\
\text { Point } \\
\text { (H) }\end{array}$} & \multirow{3}{*}{$\begin{array}{l}\text { Pelton Wheel } \\
\text { Turbine }\end{array}$} & $50 \mathrm{~mm}$ & 345.85 & 75.71 & 30.67 & 5.76 & 1285.15 & 156.73 & 5.93 & 0.72 \\
\hline & & $100 \mathrm{~mm}$ & 397.43 & 77.45 & 35.26 & 5.62 & 1484.96 & 119.06 & 6.85 & 0.55 \\
\hline & & $150 \mathrm{~mm}$ & 351.22 & 76.90 & 31.16 & 5.88 & 1307.59 & 171.30 & 6.03 & 0.79 \\
\hline & \multirow{3}{*}{$\begin{array}{l}\text { Cross Flow } \\
\text { Turbine }\end{array}$} & $50 \mathrm{~mm}$ & 201.04 & 58.54 & 24.43 & 6.43 & 684.00 & 97.31 & 3.16 & 0.45 \\
\hline & & $100 \mathrm{~mm}$ & 224.61 & 59.54 & 27.28 & 6.39 & 751.78 & 60.73 & 3.47 & 0.28 \\
\hline & & $150 \mathrm{~mm}$ & 177.09 & 49.06 & 21.51 & 5.32 & 592.11 & 64.18 & 2.73 & 0.30 \\
\hline
\end{tabular}

Table 2: Effect of Load on Turbine Speed and Turbine Torque

\begin{tabular}{|c|c|c|c|c|c|c|c|}
\hline \multicolumn{3}{|l|}{ Type } & \multirow{2}{*}{$\begin{array}{c}\text { Sum of Squares } \\
654240.895\end{array}$} & \multirow{2}{*}{$\begin{array}{l}\text { df } \\
1\end{array}$} & \multirow{2}{*}{$\begin{array}{c}\text { Mean Square } \\
654240.895\end{array}$} & \multirow{2}{*}{$\frac{F}{284.674}$} & \multirow{2}{*}{$\begin{array}{c}\text { Sig. } \\
0.001^{*}\end{array}$} \\
\hline \multirow{6}{*}{  } & \multirow{3}{*}{ Turbine Speed } & Between Groups & & & & & \\
\hline & & Within Groups & 367713.605 & 160 & 2298.210 & & \\
\hline & & Total & 1021954.500 & 161 & & & \\
\hline & \multirow{3}{*}{ Turbine Torque } & Between Groups & 3088.107 & 1 & 3088.107 & 172.631 & $0.001^{*}$ \\
\hline & & Within Groups & 2862.157 & 160 & 17.888 & & \\
\hline & & Total & 5950.263 & 161 & & & \\
\hline \multirow{6}{*}{ 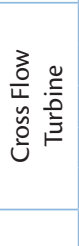 } & \multirow{3}{*}{ Turbine Speed } & Between Groups & 409613.062 & 1 & 409613.062 & 441.680 & $0.001^{*}$ \\
\hline & & Within Groups & 148383.728 & 160 & 927.398 & & \\
\hline & & Total & 557996.790 & 161 & & & \\
\hline & Turbine Torque & Between Groups & 4599.471 & 1 & 4599.471 & 340.910 & $0.001^{*}$ \\
\hline & & Within Groups & 2158.680 & 160 & 13.492 & & \\
\hline & & Total & 6758.151 & 161 & & & \\
\hline
\end{tabular}

Table 3: Comparing the mean values of Turbine Speed and Turbine Torque using Duncan Multiple Range Test

\begin{tabular}{|c|c|c|c|}
\hline Turbine Type & Level & Turbine Speed & Turbine Torque \\
\hline $\begin{array}{c}\text { Pelton Wheel } \\
\text { Turbine }\end{array}$ & Off Load & $428.38 \mathrm{a}$ & $36.73 \mathrm{a}$ \\
\cline { 2 - 4 } & On Load & $301.28 \mathrm{~b}$ & $28.00 \mathrm{~b}$ \\
\hline Cross Flow Turbine & Off Load & $251.20 \mathrm{a}$ & $29.74 \mathrm{a}$ \\
\cline { 2 - 4 } & On Load & $150.63 \mathrm{~b}$ & $19.08 \mathrm{~b}$ \\
\hline
\end{tabular}

Means with the same alphabet are not significantly different from each other

\subsection{Comparing the Output from Pelton Wheel Turbine and Cross Flow Turbine}

Generally, for all process parameter measured, the Pelton Wheel Turbine recorded higher mean values than the Crossflow Turbine. This could be due to the optimization of the operating conditions. Similarly, Tilahun et.al.[12] reported that Changing the length, depth, angular position (Jet bucket interaction), and number of the buckets while keeping all other parameters constant could improve maximum ef- ficiency of Pelton wheel and reduce production cost. Table 4 compares the process output namely; Turbine Speed, Turbine Torque, Alternator Speed and Output Voltage between the two Turbines. The result of this comparison shows that there was a significant difference between all the process outputs of the two Turbines at 5\% level of significance. This implies that the two Turbines did not record the same mean value of the process output.

The result of the multiple comparisons of the means of process output is as presented in Table 5. For ease of interpretation, the result on Table 5 was represented using graphical illustration on Figure 6. The mean value of Turbines speed observed in Pelton Wheel Turbine was significantly higher than the mean value of Turbine speed observed using Cross Flow Turbine. This inference is consistent for all other process output. 


\begin{tabular}{|c|c|c|c|c|c|c|c|c|}
\hline \multirow{4}{*}{$\begin{array}{l}\text { Turbine } \\
\text { Speed }\end{array}$} & \multicolumn{2}{|c|}{  } & \multicolumn{2}{|c|}{$\begin{array}{l}\text { Sum of } \\
\text { Squares }\end{array}$} & df & Mean Square & $F$ & Sig. \\
\hline & \multicolumn{2}{|c|}{ Between Groups } & \multicolumn{2}{|c|}{919217.34} & 1 & 919217.34 & 910.30 & 0.001 \\
\hline & \multicolumn{2}{|c|}{ Within Groups } & \multicolumn{2}{|c|}{161567.36} & 160 & 1009.80 & & \\
\hline & \multicolumn{2}{|c|}{ Total } & \multicolumn{2}{|c|}{1080784.70} & 161 & & & \\
\hline \multirow{3}{*}{$\begin{array}{l}\text { Turbine } \\
\text { Torque }\end{array}$} & \multicolumn{2}{|c|}{ Between Groups } & \multicolumn{2}{|c|}{3223.15} & 1 & 3223.15 & 302.98 & 0.001 \\
\hline & \multicolumn{2}{|c|}{ Within Groups } & \multicolumn{2}{|c|}{1702.09} & 160 & 10.64 & & \\
\hline & \multicolumn{2}{|c|}{ Total } & \multicolumn{2}{|c|}{4925.25} & 161 & & & \\
\hline \multirow{3}{*}{$\begin{array}{c}\text { Alternator } \\
\text { Speed }\end{array}$} & \multicolumn{2}{|c|}{ Between Groups } & \multicolumn{2}{|c|}{18910000.00} & 1 & 18910000.00 & 941.51 & 0.001 \\
\hline & \multicolumn{2}{|c|}{ Within Groups } & \multicolumn{2}{|c|}{3213211.43} & 160 & 20082.57 & & \\
\hline & \multicolumn{2}{|c|}{ Total } & \multicolumn{2}{|c|}{22120000.00} & 161 & & & \\
\hline \multirow[t]{3}{*}{$\begin{array}{l}\text { Output } \\
\text { Voltage }\end{array}$} & \multicolumn{2}{|c|}{ Between Groups } & \multicolumn{2}{|c|}{402.84} & 1 & 402.84 & 941.87 & 0.001 \\
\hline & \multicolumn{2}{|c|}{ Within Groups } & \multicolumn{2}{|c|}{68.43} & 160 & 0.43 & & \\
\hline & \multicolumn{2}{|c|}{ Total } & \multicolumn{2}{|c|}{471.27} & 161 & & & \\
\hline \multicolumn{9}{|c|}{ Table 5: Comparing the Mean of Process Output from the two Turbines } \\
\hline \multicolumn{2}{|c|}{ Turbine Type } & \multicolumn{2}{|c|}{$\begin{array}{l}\text { Turbine } \\
\text { Speed }\end{array}$} & \multicolumn{2}{|c|}{$\begin{array}{l}\text { Turbine } \\
\text { Torque }\end{array}$} & $\begin{array}{l}\text { Alternator } \\
\text { Speed }\end{array}$ & \multicolumn{2}{|c|}{$\begin{array}{l}\text { Output } \\
\text { Voltage }\end{array}$} \\
\hline \multicolumn{2}{|c|}{$\begin{array}{l}\text { Pelton Wheel } \\
\text { Turbine }\end{array}$} & 301.2 & $28 \mathrm{a}$ & & $.00 \mathrm{a}$ & $1359.23 a$ & 6.2 & \\
\hline $\begin{array}{r}\text { Cross } \\
\text { Turb }\end{array}$ & $\begin{array}{l}\text { Flow } \\
\text { bine }\end{array}$ & 150.6 & & & $.08 \mathrm{~b}$ & $675.96 b$ & & \\
\hline
\end{tabular}

\subsection{Optimization Analysis}

The optimized value of operating conditions namely; angle of inclination, height to impact point and length to impact point pre-set at their various levels for both Turbines and the optimum values of the process output or measured parameters are as presented in Table 6. The processes were optimized for both on load and off load.

\section{Off-Load Condition}

a. To optimize Turbine speed in off load condition, $250 \mathrm{~mm}$ height to impact point, $150 \mathrm{~mm}$ length to impact point and angle at tangential inclination will be required. This combination will yield an optimum Turbine speed of 538.38rpm. Similar combination will also yield a Turbine Torque of 46.16kNm for same Pelton Wheel Turbine.

b. For Cross Flow Turbine in off load condition however, an optimum Turbine Speed of 330.09rpm was achieved by pre-setting $250 \mathrm{~mm}$ height to impact point, $100 \mathrm{~mm}$ length to impact point and $15^{\circ} \mathrm{C}$ below tangent. Same combination for yielded a Turbine Torque of 39.07kNm.

\section{On-Load Condition}

a. For Pelton Turbine Wheel, Optimum Turbine speed of $392.02 \mathrm{rpm}$ was achieved at $250 \mathrm{~mm}$ height to impact point, $150 \mathrm{~mm}$ length to impact point and at tangential angle of inclination. Same process combination yielded an optimum Turbine Torque of $36.46 \mathrm{kNm}$, and Alternator speed of 1768.56rpm and an output voltage of $7.87 \mathrm{~V}$.

b. For Cross Flow Turbine, an optimum Turbine speed of $197.66 \mathrm{rpm}$ was achieved at pre-set level of $250 \mathrm{~mm}$ height to impact point, $100 \mathrm{~mm}$ length to impact point and at $15^{\circ}$ below tangent. These same combinations will yield a Turbine Torque of $25.02 \mathrm{kNm}$, and Alternator speed of $879.24 \mathrm{rpm}$ and $4.05 \mathrm{~V}$

Table 6: Optimized Values of Operating Conditions and Output

\begin{tabular}{|c|c|c|c|c|c|c|c|}
\hline & & Parameters & $\mathbf{H}$ & I & V & $\begin{array}{c}\text { Optimi- } \\
\text { zed } \\
\text { value }\end{array}$ & $\begin{array}{l}\text { Nature of } \\
\text { Solution }\end{array}$ \\
\hline \multirow{4}{*}{$\frac{\pi}{\frac{\pi}{0}}$} & \multirow{2}{*}{$\begin{array}{l}\text { Pelton } \\
\text { Wheel } \\
\text { Turbine }\end{array}$} & $\begin{array}{l}\text { Turbine } \\
\text { Speed }\end{array}$ & $250 \mathrm{~mm}$ & Tangential & $150 \mathrm{~mm}$ & 538.38 & $\begin{array}{c}\text { Maximi- } \\
\text { zed }\end{array}$ \\
\hline & & $\begin{array}{l}\text { Turbine } \\
\text { Torque }\end{array}$ & $250 \mathrm{~mm}$ & Tangential & $150 \mathrm{~mm}$ & 46.15 & $\begin{array}{l}\text { Maximi- } \\
\text { zed }\end{array}$ \\
\hline & \multirow{2}{*}{$\begin{array}{l}\text { Cross } \\
\text { Flow } \\
\text { Turbine }\end{array}$} & $\begin{array}{l}\text { Turbine } \\
\text { Speed }\end{array}$ & $250 \mathrm{~mm}$ & $15^{\circ}$ below & $100 \mathrm{~mm}$ & 330.09 & $\begin{array}{l}\text { Maximi- } \\
\text { zed }\end{array}$ \\
\hline & & $\begin{array}{l}\text { Turbine } \\
\text { Torque }\end{array}$ & $250 \mathrm{~mm}$ & $15^{\circ}$ below & $100 \mathrm{~mm}$ & 39.07 & $\begin{array}{c}\text { Maximi- } \\
\text { zed }\end{array}$ \\
\hline \multirow{8}{*}{$\frac{\text { T }}{\frac{0}{1}}$} & \multirow{4}{*}{$\begin{array}{c}\text { Pelton } \\
\text { Wheel } \\
\text { Turbine }\end{array}$} & $\begin{array}{l}\text { Turbine } \\
\text { Speed }\end{array}$ & $250 \mathrm{~mm}$ & Tangential & $150 \mathrm{~mm}$ & 392.02 & $\begin{array}{c}\text { Maximi- } \\
\text { zed }\end{array}$ \\
\hline & & $\begin{array}{l}\text { Turbine } \\
\text { Torque }\end{array}$ & $250 \mathrm{~mm}$ & Tangential & $150 \mathrm{~mm}$ & 36.46 & $\begin{array}{c}\text { Maximi- } \\
\text { zed }\end{array}$ \\
\hline & & $\begin{array}{c}\text { Alternator } \\
\text { Speed }\end{array}$ & $250 \mathrm{~mm}$ & Tangential & $150 \mathrm{~mm}$ & 1768.56 & $\begin{array}{c}\text { Maximi- } \\
\text { zed }\end{array}$ \\
\hline & & $\begin{array}{l}\text { Output } \\
\text { Voltage }\end{array}$ & $250 \mathrm{~mm}$ & Tangential & $150 \mathrm{~mm}$ & 7.87 & $\begin{array}{c}\text { Maximi- } \\
\text { zed }\end{array}$ \\
\hline & \multirow{4}{*}{$\begin{array}{c}\text { Cross } \\
\text { Flow } \\
\text { Turbine }\end{array}$} & $\begin{array}{l}\text { Turbine } \\
\text { Speed }\end{array}$ & $250 \mathrm{~mm}$ & $15^{\circ}$ below & $100 \mathrm{~mm}$ & 197.66 & $\begin{array}{c}\text { Maximi- } \\
\text { zed }\end{array}$ \\
\hline & & $\begin{array}{l}\text { Turbine } \\
\text { Torque }\end{array}$ & $250 \mathrm{~mm}$ & $15^{\circ}$ below & $100 \mathrm{~mm}$ & 25.02 & $\begin{array}{c}\text { Maximi- } \\
\text { zed }\end{array}$ \\
\hline & & $\begin{array}{c}\text { Alternator } \\
\text { Speed }\end{array}$ & $250 \mathrm{~mm}$ & $15^{\circ}$ below & $100 \mathrm{~mm}$ & 879.24 & $\begin{array}{c}\text { Maximi- } \\
\text { zed }\end{array}$ \\
\hline & & $\begin{array}{l}\text { Output } \\
\text { Voltage }\end{array}$ & $250 \mathrm{~mm}$ & $15^{\circ}$ below & $100 \mathrm{~mm}$ & 4.05 & $\begin{array}{l}\text { Maximi- } \\
\text { zed }\end{array}$ \\
\hline
\end{tabular}

$H=$ height to impact point, $I=$ angle of inclination and $V=$ length to impact point

\section{CONCLUSION AND RECOMMENDATIONS}

\subsection{Conclusion}

The performance of the two turbines (Pelton Wheel and Crossflow Turbines) were evaluated and the optimized operating conditions (angle of inclination, height to impact point and length to impact point) pre-set at their various levels for both Turbines and the optimum values of the process output or measured parameters were determined statistically. The results showed that there was a loading effect as the turbine torque and speed declined after loading the two turbines. This suggests that both turbines should not be loaded beyond the designed limit for optimal performance. The most efficient turbine at these operating conditions was the Pelton wheel turbine. This could mean that if the operating condition is optimized, the Pelton wheel could as well be adapted to flows with very low heads. From the optimization of the operating conditions, it could be inferred that both turbines performed better at a height to impact point of $250 \mathrm{~mm}$ (coinciding with the highest point on the turbine cup/blade). This could mean that the turbine derives more energy from the flowing water when the jet is directed towards the highest point.

\subsection{Recommendation}

It is recommended that; further research should be carried out on the effects of nozzle sizes, number of pelton wheel buckets, head, discharge, etc. on all the investigated parameters; the system is modelled as it would make it easier to predict the effects of various conditions on the output; means of increasing the speed is looked into; the machines 
should be adapted for other flowing streams and rivers in the rural areas so as to make life better for those living in the rural areas who are without access to power from the national grid.

\section{REFERENCES}

[1] Akoshile, C. O. and Olaoye, J. O. (2009). Adapting Dedicated Hydro Dam for Electrical Power Generation - Unilorin Case Study. A paper presented at a 2 - Day Seminar on Hydropower Resources: Development, Management and the Environment Organized by the National Centre for Hydropower Research and Development.

[2] Aliyu, U.P. and Elegba, S. B. (1990). Prospects for Small Hydropower Development for Rural Applications in Nigeria. Nigerian Journal of Renewable Energy, 1(1): 74-86

[3] Craig, H. R. and COX, H. J. (1971). Performance Estimation of Axial Flow Turbines. The Institution of Mechanical Engineers (Thermodynamics and Fluid Mecahincss Group), 185: 32-71.

[4] EIA. (2004). Energy Information Administration, Energy INFO card, October, 2004.

[5] Mokmore, C. A. and Merryfield, F. (1949). The Bank water turbine Bulletin. Engineering Experiment Station. Oregon, U.S.A.

[6] Okpanefe, P. E. and Owolabi, S. (2001). Small Hydropower in Nigeria. 2001 TCDC Training Workshop on Small Hydropower Programme.

[7] Olivia, P. (2008). International Consulting Limited, Nigeria: Electric Power Sector Report. ?

[8] Oyebode, O. O. (2014). Design, Fabrication and Comparative Performance Evaluation of Pelton Wheel and Crossflow Turbines for Power Generation. M.Eng. Thesis submitted to the Department of Agricultural and Biosystems Engineering, (TEZ)

[9] Kraft R. A. and Same R. H. (2002). The tangential impulse water wheels in California Gold Mining. Conference proc. National association of mining history organisation

[10] Sambo, A. S. (2009). The Place of Renewable Energy in the Nigerian Energy Sector. Presented at the World Future Council Workshop on Renewable Energy Policies. Addis Ababa, Ethiopia.

[11] Staubli, T., Bissel, C. and Leduc, J. (2001). Jet Quality and Pelton Efficiency, $\mathrm{HCl}$ Publications, 2nd Edition.

[12] Tilahun N., Abraham E. and Edessa D. (2017). Design, Modelling, and CFD Analysis of a Micro Hydro Pelton Turbine Runner: For the Case of Selected Site in Ethiopia International Journal of Rotating Machinery (1): 1-17, DOI:10.1155/2017/3030217.

[13] Wikander, Orjan (2000). "The water - mill", in Wikander, Orjan Handbook of Ancient water Technology, Technology and change in history 2, Leiden: Brill, pgs. 371 - 400.

[14] Zarma, H. I. (2006). Hydropower Resources in Nigeria. Country Paper presented at 2nd Hydropower for Today Conference, International Centre on Hydropower, Hangzhou, China.

[15] Amiri, K., Mulu, B., Raisee, M., Cervantes, M. J. (2014). Load variation effects on the pressure fluctuations exerted on a Kaplan turbine runner27th IAHR Symposium on Hydraulic Machinery and Systems (IAHR 2014), p.1-10. 